\title{
PENYUSUNAN INSTRUMEN PENGUKURAN IKHLAS
}

\author{
Lu'luatul Chizanah \\ M. Noor Rochman Hadjam
}

Fakultas Psikologi Universitas Gadjah Mada Yogyakarta

Email: lu'luatul_ch@mail.ugm-ac.id

Äbstract

Ikhlas as a psychological construct does not have any instrument. Based on that fact, the research is aimed at developing a instrument so the topic of ikhlas can be developed more widely. The process of preparation carried out in three stages, namely (1) writing items of ikhlas' scale, (2) content validation through professional judgment and cognitive debriefing, and (3) testing the reliability with alpha-cronbach approach. The subjects in this study amounted to 224 people. The result of this research was a ikhlas' scale consist of 22 items. The reliability's score of scale was 0,809. It shows that the scale developed can be considered as a good instrument of ikhlas.

Keywords: ikhlas'scale, cognitive debriefing, content validation

\begin{abstract}
Abstrak
Ikhlas sebagai sebuah konstruk psikologis belum memiliki instrumen pengukuran. Berdasarkan hal tersebut, maka penelitian ini ditujukan untuk menyusun instrumen pengukuran ikhlas, sehingga kajian mengenai ikhlas dapat dikembangkan secara lebih luas. Proses penyusunan dilakukan dalam 3 tahap, yaitu (1) penulisan aitem skala ikhlas; (2) validasi isi melalui professional judgement dan cognitve debriefing; dan (3) uji reliabilitas dengan pendekatan alpha-cronbach. Subjek dalam penelitian ini berjumlah 224 orang dengan rincian 5 orang pakar tasawuf untuk memperoleh professional judgment, 19 orang representasi muslim dalam cognitive debriefing, dan 205 orang yang berpartisipasi dalam pengisian skala. Hasil penelitian ini adalah skala ikhlas yang terdiri dari 22 aitem memiliki nilai reliabilitas sebesar 0,809. Hal ini menunjukkan bahwa skala yang disusun dapat dinilai layak sebagai instrumen pengukuran ikhlas.
\end{abstract}

Katakunci: Skala ikhlas, validasi isi

$\mathrm{K}$ ajian mengenai spiritualitas dan religiositas dalam beberapa waktu Trend penelitian di bidang psikologi tampaknya mengalami pergeseran dari penelitian konfirmatif terhadap konsepkonsep yang telah mapan menuju pencarian konsep-konsep baru dalam bingkai budaya dan agama. Hal ini tercermin dalam penelusuran melalui Science Direct, ditemukan 1082 artikel penelitian dengan topik spiritualitas dan religiositas.

Belzen (2004) mengamati bahwa dalam sejumlah studi, terdapat tumpang tindih penggunaan istilah spiritualitas dan religiositas. Spiritualitas dan religiositas sesungguhnya merupakan dua hal yang berbeda. Religiositas adalah sebuah fenomena kultural makro, sementara spiritualitas adalah fenomena mikro yang berada pada level personal. Penjelasan Belzen (2004) tersebut membedakan religiositas dan spiritualitas berdasarkan domain wilayah. Akan tetapi, pada dasarnya religiositas berkaitan dengan kekuatan yang lebih tinggi (Tuhan) serta ritual-ritual dan keyakinan-keyakinan di dalamnya, sedangkan spiritualitas berkaitan dengan pengalaman-pengalaman dan perasaan untuk menjawab pertanyaan akan makna hidup dan tujuannya (Henningsgaard \& Arnau, 2008). Oleh karena itu dapat 
dikatakan bahwa religiositas akan melibatkan aspek spiritualitas, sementara spiritualitas bisa jadi sama sekali tidak melibatkan agama (Belzen, 2004).

Seiring dengan peningkatan jumlah riset terkait religiositas, maka pada penghujung abad XIX munculah satu pendekatan baru dalam psikologi yang disebut psikologi agama. APA (American Psychological Association) sendiri bahkan telah mendirikan divisi tersendiri, yaitu divisi 36, Psikologi Agama (Hood, Hill, \& Spilka, 2009), serta menerbitkan buku seputar psikologi agama (lihat Belzen, 2004). Psikologi agama merupakan cabang psikologi yang meneliti dan mempelajari fungsi-fungsi jiwa yang memantul dan memperlihatkan diri dalam perilaku dalam kaitannya dengan kesadaran dan pengalaman agama manusia (Jalaluddin, 2010).

Topik kajian dalam psikologi agama adalah konsep-konsep yang terkandung dalam agama, baik dalam satu jenis agama tertentu maupun konsep umum dalam setiap agama. Kajian dalam psikologi agama apabila kemudian ditarik ke lingkup Islam, maka konsep-konsep yang dapat dikaji adalah yang bersumber dalam khasanah literatur Islam. Khasanah Islam yang memiliki titik singgung yang dekat dengan psikologi adalah tasawuf (Khalil, 2007; Nizar, 2009). Tasawuf berkaitan dengan bagaimana cara menyucikan diri sehingga menuju pada derajat spiritualitas yang lebih tinggi. Dalam tasawuf, ikhlas merupakan salah satu konsep penting yang ditekankan selain sabar, syukur, dan ridlo (Sufi Muda, 2008).

Kemudian apa pentingnya menegaskan atau menggali konstruk ikhlas dalam konteks psikologi agama? Penelitian ini diarahkan lebih jauh untuk membentuk sebuah bangunan utuh tentang psikologi agama. Belzen (2004) secara tajam, dalam tulisannya mengkritik perkembangan penelitian di bidang psikologi agama serta praktiknya di kalangan para psikolog yang cenderung tidak profesional. Apa yang dikembangkan tidak didasari oleh temuantemuan mendalam dan berkelanjutan, sehingga kurang memiliki kejelasan konsep. Selain hal tersebut, ikhlas memiliki potensi- potensi penting sehingga layak untuk digali lebih mendalam menuju pemahaman yang empiris. Idries Shah, salah seorang tokoh tasawuf kontemporer melalui karyanya yang berjudul Learning How to Learn: Psychology and Spirituality in the Sufi way dan The Sufis, menunjukkan bahwa konsepkonsep sufi tradisional, termasuk ikhlas di dalamnya, dapat memecahkan persoalanpersoalan sosial, psikologis, dan spiritual manusia (Muhammad, 2002).

Ikhlas secara bahasa bermakna bersih, suci. Secara istilah, ikhlas diartikan sebagai niat yang murni semata-mata mengharap penerimaan dari Tuhan dalam melakukan suatu perbuatan, tanpa menyekutukan Tuhan dengan yang lain (Qalami, 2003). Definisi tersebut merupakan definisi yang substantif. Kajian dalam bingkai psikologi mengenai ikhlas secara substantif dilakukan oleh Chizanah (2009) melalui studi hermeneutika terhadap pemikiran Ghozali yang terangkum dalam buku Ihya' Ulumiddin. Dalam studinya, Chizanah menunjukkan bahwa ikhlas merupakan suatu kondisi mental yang berkaitan dengan proses berideologi sebagai hamba Tuhan.

Adanya konsep mengenai hamba Tuhan menunjukkan bahwa ikhlas merupakan konstruk yang bernuansa spiritual-religius. Spiritualitas merupakan salah satu hal yang berperan dalam pengembangan kesehatan mental (e.g Bonab, Hamikirad, \& Habibi, 2010), kualitas hidup (e.g Boero, et.al, 2005), dan kebermaknaan hidup (e.g Camordy, Reed, Kristeller, \& Merriam, 2008). Cotton, Zebracki, Rosenthal, Tsevat, dan Drotar (2006) melakukan review atas berbagai studi yang dilakukan dalam kurun waktu 19932005 dan menemukan bahwa spiritualitas/religiositas memiliki peranan penting dalam perilaku sehat, kesehatan mental, serta aspek fisik seseorang. Pada studi sebelumnya, Cotton, Larkin, Hoopes, Cromer, dan Rosenthal (2005) membuktikan bahwa peningkatan spiritualitas/religiositas memiliki peranan dalam penurunan tingkat depresi dan perilaku yang berisiko terhadap kesehatan pada remaja. Chally dan Carlson (2004) melakukan studi review literatur dan 
menemukan kaitan yang kuat antara spiritualitas dengan ketaatan dalam rehabilitasi serta penuaan.

Ikhlas dalam pemaknaan yang substantif memiliki potensi untuk dikembangkan sebagai model terapi yang baru berbasis spiritual seperti halnya terapi dzikir (Subandi, 2009) dan terapi cerita sufistik (King, 1988). Selain itu, ikhlas mampu menjelaskan fenomena kependetaan di kalangan Kristiani, pengasingan diri yang dilakukan oleh beberapa bhiksu, fanatisme agama, serta penyimpangan-penyimpangan antara laku ibadah yang rutin dengan maraknya perbuatan menyimpang dengan adanya konsep superiority feeling dan wild desire.

Selain dalam konteks spiritualitas, ikhlas terutama memiliki kontribusi penting dalam masalah moral yang saat ini menjadi fokus perhatian dari masyarakat dan pemerintah. Chizanah (2009) menunjukkan bagaimana ikhlas dapat mencegah seseorang untuk melakukan korupsi dalam konteks Indonesia saat ini dengan adanya konsep diri sebagai hamba Tuhan, kebahagiaan yang non-material, serta tanggung jawab sosial yang tinggi. Hal-hal tersebut menjadikan seseorang enggan melakukan korupsi walau sebesar apapun kesempatannya mengingat bahwa hakikat kebahagiaan adalah mencapai kedekatan dengan Tuhan. Ikhlas, dalam konteks moral, akan memberi sumbangan besar dalam ketahanan moral seseorang.

Potensi-potensi ikhlas, sebagaimana diuraikan sebelumnya, akan mungkin dikembangkan ketika ikhlas dapat dideskripsikan secara lebih praktis dan menjadi sebuah konstruk yang dapat diukur. Desakan untuk membuat konstruk psikologi ikhlas menjadi dapat diukur begitu kuat. Hal ini misalnya tercermin dari tanggapan para peserta temu ilmiah Asosiasi Psikologi Islami (API) di Malang (9-10 April 2011) atas presentasi yang dilakukan penulis. Selain itu juga adanya kegundahan penulis ketika menjumpai kenyataan yang ternyata masih ada yang salah memahami konstruk psikologi ikhlas itu sendiri. Konstruk ikhlas yang dibangun penulis menitikberatkan pada konsep penghambaan diri bukan pada kerelaan menerima kenyataan sebagaimana konsep letting go yang dicetuskan Corey (2005). Hal ini rupanya wajar terjadi pada sebuah konstruk yang baru dibangun. Ini juga dialami metaneeds Maslow di awal kemunculannya. Maslow (1971) sebagaimana dikutip oleh Hall (2008) mengatakan:

"Self-actualization is a matter of degree, or little accessions accumulated one by one. Too often our clients are inclined to wait for some kind of inspiration to strike so that they can say, 'At 3:23 in this Thursday I became self-actualized.' People selected as selfactualizing subjects, people who fit the criteria go about it in these little ways: They listen to their own voices; they take responsibility; they are honest; they work hard. They find out who they are and what they are, not only in terms of their mission in life, but also in terms of the way their feet hurt when they wear such and such a pair of shoes and whether they do or do not like eggplant or stay up all night if they drink too much beer. All this is what the real self means. They find their own biological natures, their congenital natures..." (p. 49)

Apa yang diungkapkan Maslow di atas menunjukkan kegelisahan bahwa konsep tentang aktualisasi diri ternyata tidak mudah dipahami oleh orang kebanyakan. Dalam kenyataannya, orang-orang tergesagesa memaknai aktualisasi diri dan menggunakannya dalam bahasa keseharian.

Berdasarkan uraian di atas, tampak bahwa penyusunan instrumen pengukuran ikhlas penting dilakukan. Potensi-potensi ikhlas sebagai sebuah konstruk psikologi tidak dapat tercapai secara optimal tanpa adanya sebuah instrumen pengukuran ikhlas seperti halnya instrumen pengukuran pada konsruk-konstruk psikologi yang lain. Selain itu penyusunan instrumen diharapkan juga mampu memperjelas pemahaman mengenai konstruk ikhlas. Oleh karena itu penelitian ini dilakukan untuk membangun sebuah intrumen pengukuran ikhlas. 


\section{METODE PENELITIAN}

\section{Subjek Penelitian}

Subjek penelitian berjumlah 224 orang, dengan rincian 5 orang pakar tasawuf untuk memperoleh professional judgment, 19 orang representasi muslim dalam cognitive debriefing, dan 205 orang yang berpartisipasi dalam pengisian skala.

\section{Prosedur Penelitian} tahapan, yaitu

Penelitian ini berlangsung dalam 3

1. Peneliti menyusun aitem-aitem pengamat konstruk ikhlas.

2. Validasi konten, dilakukan melalui professional judgement dan cognitive debriefing.

Professional judgement. Peneliti meminta professional judgement dari para ahli, yaitu praktisi tasawuf. Pemerolehan professional judgment dilakukan dengan teknik wawancara sekaligus untuk menggali kemungkinan adanya aitem-aitem pengamat tambahan konstruk ikhlas.

Cognitive debriefing. Peneliti melakukan FGD kepada kelompok awam yang terbagi menjadi dua kelompok. Masing-masing kelompok dikenai diskusi tentang ikhlas. Peneliti menunjukkan serangkaian aitem pengamat ikhlas dan kemudian meminta subjek menyampaikan interpretasi atas aitem-aitem yang ada.

3. Uji reliabilitas

Berdasarkan temuan-temuan dalam tahapan penelitian di atas, peneliti menyusun aitem-aitem pengamat konstruk ikhlas untuk kemudian diujikan ke lapangan dalam bentuk skala ikhlas. Skala disebarkan pada responden yang tersebar di berbagai daerah dengan latar belakang yang beragam, tetapi sesuai dengan kriteria yang diketengahkan sebelumnya. Hal ini mengindikasikan bahwa sampel dalam penelitian ini bersifat heterogen. Hal ini memang tidak cukup menguntungkan dalam pencapaian nilai realibilitas skala secara umum, tetapi dalam pengujian validitas, sampel yang heterogen memungkinkan generalisasi hasil penelitian yang lebih luas. Penyebaran skala dilakukan dengan sarana internet. Responden diundang secara personal oleh peneliti untuk berpartisipasi dalam penelitian ini. Survei melalui internent dilakukan dengan memanfaatkan jasa penyedia survei online yang dapat dijumpai di http://surveymonkey.com. Alamat situs terkait penelitian ini adalah http://surveymonkey.com/s/WG392D7 d a n http://www.surveymonkey.com/s/NX8L GFY. Data yang diperoleh kemudian diuji reliabilitas dengan pendekatan alpha-cronbach.

\section{HASIL PENELITIAN}

\section{Penulisan Aitem}

Penulisan aitem didasarkan pada 4 aspek ikhlas meliputi konsepsi diri sebagai hamba Tuhan, motif transendental, ketiadaan superiority feeling dan wild desire, serta kestabilan emosi. Peneliti menuliskan aitemaitem pengamat ikhlas sebanyak 25 butir dengan rincian sebagai berikut : 
Tabel 1. Aitem-aitem skala ikhlas sebelum divalidasi

\section{Aitem}

1. Saya percaya akan adanya Tuhan

2. Tujuan hidup saya adalah beribadah kepada Tuhan

3. Saya memiliki kuasa yang luar biasa untuk mewujudkan apapun yang saya inginkan dan tidak ada kekuatan apa pun yang bisa menghalanginya

4. Bagi saya harta bukan segalanya

5. Saya rasa manusia tidak harus mengabdikan dirinya untuk TuhanBagi saya harta bukan segalanya

6. Apa yang saya lakukan selama ini semata-mata demi mencapai kesejahteraan secara finansial karena itu adalah hal yang paling penting dalam hidup

7. Saya berharap apapun yang saya lakukan, akan bisa menambah kedekatan dengan Tuhan

8. Apabila saya menolak melakukan sesuatu maka itu adalah demi menghindari kemarahan Tuhan

9. Dalam hidup ini, saya tidak peduli apakah Tuhan marah atau tidak kepada saya, karena saya tidak bisa merasakannya, oleh karenanya yang paling penting adalah saya senang

10. Saya merasa bangga atas apa yang pernah saya lakukan karena belum tentu orang lain bisa melakukan seperti saya

11. Saya suka menjadi populer

12. Ketika berbelanja, saya sulit mengontrol keinginan untuk membeli banyak barang

13. Saya ingin orang lain bisa menyadari kebaikan-kebaikan saya

14. Saya merasa risih ketika orang lain mulai mengelu-elukan saya

15. Saya sering berpikir bahwa kehendak saya harus dapat tercapai

16. Saya tidak peduli atas segala pendapat orang lain tentang saya

17. Saya tidak merasa perlu menjaga perilaku saya ketika di tengah masyarakat, sebab tidak ada perbedaan dalam perilaku saya antara di saat sendiri dan ada orang lain

18. Saya frustrasi ketika orang lain lebih baik dari saya

19. Saya orang yang mudah marah

20. Saya mudah terharu

21. Kegagalan dalam usaha sangat mudah mengendorkan semangat saya

22. Dipergunjingkan oleh orang lain sangat mudah membuat saya sedih dan kecewa

23. Saya selalu bersemangat dalam berusaha walaupun hasilnya tidak sesuai harapan

24. Selama ini saya tidak dapat terlalu gembira, bahkan ketika memperoleh keberhasilan

25. Bagi saya kegagalan dan keberhasilan itu sama saja

Aitem-aitem pada Tabel 1 terdiri dari aitem favourable dan unfavourable. Aitem favourable meliputi aitem-aitem nomor 1, 2, 5, 6, 7, 13, 14, 19, 22, 24, dan 25. Aitem unfavourable meliputi aitem-aitem nomor 3, 4, 8, 9, 10, 11, 12, 15, 17, 18, 20, 21, 22, dan 23.

\section{Validasi Konten}

\section{a. Professional Judgement}

Berdasarkan hasil dari professional judgement, diketahui bahwa aitem-aitem yang diterima adalah sebanyak 18 butir dan 7 lainnya ditolak. Sejumlah 18 butir tersebut meliputi aitem-aitem 1, 2, 3, 4, 5, 6, 7, 8, 9, $11,12,13,14,15,18,19,13$, dan 25. Akan tetapi, khusus untuk aitem 24 diselamatkan berdasar pertimbangan yang diberikan oleh expert 3 untuk melakukan modifikasi sehingga aitem tersebut berbunyi "Saya lebih mengharap ridlo Tuhan dan saya tidak tahu apakah saya diridloi atau tidak, oleh karena itu selama ini saya tidak dapat terlalu gembira bahkan ketika memperoleh keberhasilan". Selain itu terdapat tambahan 
aitem yang disampaikan oleh expert 3 dan expert 4, yaitu (1) Kerelaan saya untuk berkorban hanya semata untuk wanita/pria yang saya cintai (aitem unfavourable), (2) Apapun yang saya lakukan didasari keyakinan bahwa segala sesuatu itu dari dan untuk Tuhan (aitem favourable), dan (3) Selama ini, saya selalu melakukan segala sesuatu sesuai tuntunan Tuhan (aitem favourable). Oleh karena itu total aitem yang dinilai valid berdasar professional judgment adalah sebanyak 22 aitem, dengan rincian 12 aitem favourable dan 10 aitem favourable.

Tabel 2. Skoring Aitem berdasar professionaljudgement

\begin{tabular}{|c|c|c|c|}
\hline $\begin{array}{c}\text { Aitem } \\
\text { No. }\end{array}$ & Skor & Diterima/ditolak & Keterangan \\
\hline 1. & 1.00 & DITERIMA & (ditambah keesaan Tuhan) \\
\hline 2. & 0.8 & DITERIMA & \\
\hline 3. & 0.6 & DITERIMA & \\
\hline 4. & 0.6 & DITERIMA & \\
\hline 5. & 1.00 & DITERIMA & \\
\hline 6. & 1.00 & DITERIMA & \\
\hline 7. & 0.8 & DITERIMA & \\
\hline 8. & 0.6 & DITERIMA & \\
\hline 9. & 0.8 & DITERIMA & \\
\hline 10. & 0.2 & DITOLAK & \\
\hline 11. & 0.6 & DITERIMA & \\
\hline 12. & 0.8 & DITERIMA & \\
\hline 13. & 0.8 & DITERIMA & \\
\hline 14. & 0.8 & DITERIMA & $\begin{array}{l}\text { (ditambah 'karena saya hanya merasa dinilai oleh } \\
\text { Tuhan') }\end{array}$ \\
\hline 15. & 0.6 & DITERIMA & \\
\hline 16. & 0.4 & DITOLAK & \\
\hline 17. & 0.4 & DITOLAK & \\
\hline 18. & 0.8 & DITERIMA & \\
\hline 19. & 0.6 & DITERIMA & \\
\hline 20. & 0.2 & DITOLAK & \\
\hline 21. & 0.00 & DITOLAK & \\
\hline 22. & 0.4 & DITOLAK & \\
\hline 23. & 0.6 & DITERIMA & \\
\hline 24. & 0.2 & DITOLAK & $\begin{array}{l}\text { Diselamatkan dengan modi fikasi (atas saran dari } \\
\text { expert } 3 \text { ) }\end{array}$ \\
\hline 25. & 0.6 & DITERIMA & \\
\hline
\end{tabular}

\section{b. Cognitve Debriefing}

Cognitive debriefing dilakukan melalui pengadaan FGD (Focused Discussion Group) terhadap tiga kelompok, dengan rincian 2 kelompok santri dan 1 kelompok awam. Dalam praktiknya, masingmasing partisipan diminta pendapatnya mengenai (1) makna ikhlas sebagaimana dipahami selama ini, (2) makna ikhlas sebagaimana ilustrasi yang diajukan peneliti, dan (3) aitem-aitem pengamat ikhlas yang telah divalidasi melalui professional judgment.

Berdasar hasil analisis, makna ikhlas yang dipahami oleh partisipan dapat dikategorikan menjadi tiga hal:

\section{Kerelaan atas situasi}

Definisi ini menyiratkan bahwa ikhlas merupakan suatu bentuk reaksi pasif terhadap kenyataan, baik yang menyenangkan maupun yang tidak menyenangkan. Responden yang memaknai $\mathrm{ikhlas}$ sebagaimana tersebut, menghubungkan ikhlas dengan suatu strategi untuk dapat terbebas dari rasa penyesalan, kesedihan atas peristiwa kehilangan, musibah, kekecewaan, dan kelemahan diri. Hal ini tampak pada pernyataan responden sebagai berikut:

"Ikhlas ya uda ga mikir apa-apa lagi...Ya kalo seumpama kehilangan sesuatu ya udah..."

"Ya..ketika kita mengalami kehilangan ini atau kita diuji apa, kita ya ikhlas takdir kita seperti ini, tanpa harus mengeluh seperti apa..."

"Ikhlas itu menerima sesuatu yang berlawanan dengan yang kita pengen, hem yaudah.."

Responden lain menghubungkan ikhlas dengan sikap menerima kenyataan yang menyenangkan yang ditunjukkan dengan sikap tidak sombong. Hal tersebuat sebagaimana pernyataan responden sebagai berikut:

"Tapi menurut saya kalau mendapat sesuatu yang menggembirakan istilahnya juga harus diterima dengan ikhlas, tidak jadi sombong dan sebagainya..."

Definisi ikhlas sebagaimana pada poin ini muncul baik dalam kelompok santri maupun kelompok awam. Ini menunjukkan bahwa definisi ini bersifat populer atau dipahami oleh kebanyakan orang secara umum.

2. Ketiadaan pamrih

Ikhlas dihubungkan dengan bentuk perilaku yang aktif, yaitu menolong atau memberi secara sukarela tanpa mengharap imbalan. Perilaku yang didasari keikhlasan dilakukan dengan senang hati, tanpa beban, dan tidak ada harapan akan mendapat balasan di kemudian hari. Hal ini ditunjukkan dengan jawaban responden sebagai berikut: 
“Plong hatinya mbak ... Yaa tanpa mengharap imbalan sesuatu dari orang lain kayak kita misal sodaqoh kita tidak ingin uang itu kembali lagi padakita gitu."

"Ikhlas bagi saya itu lillahita'ala.... Walaupun sulit untuk bisa berikhlas tapi pengertian ikhlas itu kaan segala sesuatu itu tidak mengenal pamrih, ya istilahnya begitu saja. Tanpa ada imbalan apa2 kita melakukan segala itu Ya Allah dengan senang hati tanpa terbebani apapun"

Definisi di atas berbeda dengan definisi pada poin pertama yang lebih bersifat reaktif. Definisi pada poin kedua ini menyiratkan bahwa ikhlas merupakan suatu bentuk perbuatan aktif yang mengarah pada altruisme.

3. Pengharapan akan ridlo Tuhan

Ikhlas dihubungkan dengan motif dalam berperilaku yang diarahkan untuk mencapai ridlo Tuhan. Hal ini secara tersirat menunjukkan bahwa ikhlas merupakan bentuk kedekatan spiritual dengan Tuhan, artinya Tuhan menjadi pendorong dalam berperilaku. Ini tampak sebagaimana jawaban responden sebagai berikut:

"Ikhlas itu tidak mengharap sesuatu kecuali ridlonya Allah... Kalo kita menolong seseorang kita tidak mengharap apa-apa kecuali hanya Allah saja yang kita harapkan"

Definisi pada poin ketiga jauh berbeda dengan definisi pada poin pertama. Definisi pada poin ini lebih dekat dengan definisi pada poin kedua yang sama-sama menghubungkan ikhlas dengan perbuatan aktif, akan tetapi pada definisi ketiga, ikhlas tidak 'tanpa pamrih'. Definisi ketiga menunjukkan bahwa ikhlas tetap memiliki pamrih, walau sifatnya abstrak dan nonmaterial, yaitu keridloan Tuhan.

Makna-makna ikhlas sebagaimana dipaparkan di atas, kemudian dielaborasi lebih mendalam, sehingga dapat dihimpun bentuk-bentuk perilaku ikhlas yang dapat menjadi indikator ikhlas, meliputi menganggap sebagai ketetapan, memunculkan asumsi-asumsi positif, (3) merelakan, (4) mengalah, (5) tidak iri, dengki, dan tanpa ambisi, (6) memaklumi situasi, (7) tidak pamer, dan (8) melupakan peristiwa.

Berbeda dengan ikhlas, bentuk perilaku tidak ikhlas dihubungkan dengan adanya keterpaksaan dan emosi-emosi negatif seperti kesal, marah, dan kecewa. Ini sebagaimana tercermin dalam jawaban responden sebagai berikut:

"Ya di situ kita kecewa, ini, ini, ini, dan yang ada kan kita Cuma muring-muring tanpa jelas, terus malah ke kita itu jadinya sakit, itukan jadi dampak dari ketidakikhlaskan kita itu ya, jadi kita kepikiran, aduh saya kok begini, saya kok gak bisa-bisa ngerjakan ini, nah seperti itu."

\section{"Rasanya itu yah empeeeeet banget."}

Pandangan responden tentang ikhlas mengalami pergeseran setelah peneliti mengajukan ilustrasi tentang ikhlas yang telah dipersiapkan. Pergeseran definisi dinilai tidak terlalu jauh, artinya terdapat benang merah di dalamnya, sebagaimana diakui responden berikut:

“...(Terus menurut dengan definisi yang disampaikan di awal ada perbedaan nggak?) Perbedaanya sedikit..kalau di situ tentang ibadah kalau yang tadi kan kita tentang Islam.... Persamaan di lillahhitaala..berarti tadi yang menerima,menerima karena Allah, yang ingin melakukan, melakukan karena Allah. (Berarti poin ikhlasnnya tadi?) Jadi ikhlas adalah sesuatu yang karena Allah."

"Kalau menurut saya bukan pergeseran makna yah cuman ada kaitannya, ikhlas tidak dapat berdiri sendiri tanpa sifat-sifat yang lain, jadi menurut saya dari ilustrasi yang dibacakan, itu bukan pergeseran makna dari definis ikhlas yang pertama menurut saya. Yang pertama kan ikhlas itu ada kaitannya dengan sabar, artinya kita berusaha terlebih dahulu kemudian kalau kita tidak bisa, nanti kita tawakal kita mengikhlaskan, gitu. Untuk kedua itu ikhlas itu karena lillahitaala, nah tawakal itu kan 
diserahkan kepada Allah makanya ikhlas, itu juga karena Allah gitu loh, artinya kembalinya tetep kepada Allah, cuman itu sangat berkaitan saja. Kaitan itu sangat integral, jadi tidak bisa dipisahkan."

"Kalau yang tadi itu ikhlas menurut saya itu, apa sih, tujuannya buat kita sendiri gitu loh, tapi yang ini tadi, intinya buat dapat pahala"

Para responden dalam ketiga kelompok memberikan definisi ikhlas berdasar ilustrasi, yaitu "mengharap ridlo Tuhan" atau sesuai dengan definisi poin ketiga yang dijelaskan di muka. Elaborasi lebih lanjut mengenai bentuk-bentuk perilaku yang terkait dengan definisi tersebut yang dapat dirangkum sebagai indikatorindikator ikhlas dan tidak ikhlas, dijelaskan dalam tabel berikut :

Tabel 5. Indikator-indikator Ikhlas dan Tidak Ikhlas berdasar hasil FGD

\begin{tabular}{ll}
\hline Indikator Ikhlas & 1. Tidak Pamer \\
& 2. Lillahi Ta'ala \\
3. Perasaan positif \\
4. Motif tunggal \\
5. Kepeduliaan sosial tinggi \\
6. Tidak Terpaksa \\
7. Tanpa pamrih \\
8. Segala sesuatu dari Tuhan \\
Indikator Tidak Ikhlas \\
1. Orientasi kepada diri sendiri \\
2. Perasaan negatif \\
3. Ingin tampak menonjol \\
4. Pencitraan
\end{tabular}

Temuan di atas menunjukkan adanya kesamaan pandangan responden dengan apa yang dipaparkan Chizanah (2009) tentang konstruk psikologi ikhlas berdasar literatur Islam.

Tujuan penting dari FGD yang dilakukan adalah mendapatkan validasi dari para responden atas aitem-aitem pengamat ikhlas yang telah divalidasi sebelumnya oleh pakar tasawuf. Validasi dilakukan dengan meminta interpretasi responden atas pernyataan-pernyataan aitem pengamat. Peneliti kemudian menganalisis kesesuaian maksud pernyataan yang dibuat dengan apa yang diinterpretasikan oleh responden. Apabila interpretasi tidak sesuai dengan yang dimaksudkan dalam pernyataan, maka peneliti melakukan modifikasi yang seketika dikonfirmasikan kembali kepada responden.
Berdasar hasil interpretasi responden, maka secara umum ke-22 aitem pengamat dapat diinterpretasi sebagaimana yang dimaksudkan, tetapi atas saran responden pernyataan yang berbunyi "Bagi saya harta bukan segalanya" dimodifikasi menjadi "Harta memang penting, akan tetapi harta bukan segalanya".

Dalam sesi ini, terdapat kesulitan bagi peneliti agar responden mengerti apa yang dimaksud dengan interpretasi. Dalam praktiknya, responden cenderung memberikan penilaian kesesuaian pernyataan dengan konteks ikhlas. Oleh karena itu dalam analisis hasil interpretasi, peneliti tidak memperhatikan pendapat yang disampaikan responden yang berkaitan dengan kesepakatan atau ketepatan pernyataan tersebut dengan konteks ikhlas, tetapi peneliti menganalisis apa yang dipahami oleh responden dari pernyataan tersebut yang disampaikan secara implisit. Ini misalnya pada aitem yang berbunyi "Apabila saya menolak sesuatu, maka itu adalah demi menghindari kemarahan Tuhan", responden pada Kelompok santri 1 tidak sepakat akan aitem tersebut dan menyatakan bahwaa pernyataan itu terkait dengan ketaatan. Pada kasus ini, yang dimaksudkan oleh aitem tersebut adalah ketaatan. Oleh karena itu aitem tersebut dinilai memiliki kesesuaian pemaknaan.

\section{Uji reliabilitas}

Responden yang berhasil dikumpulkan adalah sebanyak 239. Jumlah tersebut kemudian disortir berdasarkan kesesuaian kualifikasi serta kelengkapan jawaban, sehingga pada akhirnya diperoleh data dari 205 responden. Jumlah ini menjadi jumlah sampel dalam uji reliabilitas ini.

Pendekatan estimasi reliabilitas yang digunakan dalam penelitian ini adalah reliabilitas konsistensi internal alphacronbach. Koefisien reliabilitas berkisar dari skor 0,00 hingga 1,00 dengan asumsi bahwa semakin mendekati angka 1,00, maka semakin reliabel alat ukur tersebut. Estimasi reliabilitas seluruh aitem dalam skala ikhlas menghasilkan skor alpha 0,809. Koefisien ini menunjukkan bahwa skala ikhlas memiliki reliabilitas yang baik dan dapat dipercaya 
hasil pengukurannya.

\section{PEMBAHASAN}

Dalam penelitian ini, indikatorindikator ikhlas disusun berdasar hasil penelitian Chizanah (2009) tentang konstruk psikologi ikhlas. Aspek-aspek penting dalam ikhlas meliputi konsep diri sebagai hamba Tuhan, motif transendental dalam berperilaku, ketiadaan elemen perusak yang meliputi superiority feeling dan wild desire, serta pe emosi. Berdasar atas aspek-aspek tersebut maka disusun indikator-indikator ikhlas sejumlah 25 aitem. Kemudian, indikator-indikator tersebut diajukan kepada 5 orang pakar tasawuf untuk memperoleh professional judgment. Berdasarkan penilaian para pakar tersebut kemudian diperoleh 19 aitem yang dinilai valid dan ditambah 3 aitem yang disarankan oleh pakar, sehingga total aitem berjumlah 22 .

Indikator-indikator tersebut kemudian disajikan kepada representasi masyarakat pada umumnya, yang diwakili oleh dua kelompok yaitu kelompok santri dan non-santri, dengan jumlah masingmasing kelompok adalah 5 orang. Tujuannya adalah untuk memastikan bahwa pernyataanpernyataan pada tiap aitem dapat dipahami sebagaimana dimaksudkan. Teknik demikian disebut sebagai cognitive debriefing.

Cognitive debriefing pada dasarnya merupakan sebuah metode yang dikembangkan untuk pengembangan dan modifikasi alat ukur serta validasi linguistik untuk instrumen yang digunakan dalam skala internasional. Tujuan utama dari cognitive debriefing adalah memastikan apakah pertanyaan atau aitem-aitem dalam instrumen dapat dipahami sebagaimana dimaksudkan oleh penyusun alat atau pertanyaan itu sendiri (Teschendorf, 2011). Secara teknis, cognitive debriefing dilakukan dengan menyajikan instrumen kepada partisipan untuk direspon. Respon partisipan berupa uraian interpretasi atas tiap aitem dalam instrumen. Apabila terjadi ketidakcocokan, maka instrumen perlu dimodifikasi dan selanjutnya dilakukan cognitive debriefing lagi. Cognitive debriefing dapat dikenakan pada partisipan secara personal atau kelompok. Cognitive debriefing banyak digunakan dalam keperluan klinis, misalnya untuk melakukan validitas konten instrument patient-reported outcome (PRO). Ploughman, Austin, Stefanelli, dan Godwin (2010) membuktikan bahwa penggunaan cognitive debriefing dapat meningkatkan ketepatan instrumen untuk populasi khusus. Dalam studi tersebut juga dicatat beberapa hal yang memunculkan galat dalam cognitive debriefing, yaitu pertama responden tidak membaca instruksi dan melengkapi aitem-aitem secara tidak tepat, kedua responden tidak memahami pertanyaan dan memerlukan contoh-contoh sebagai klarifikasi, dan ketiga responden merasa pilihan respon tidak ada yang sesuai dengan keadaan dirinya. Berdasar hal tersebut, peneliti melakukan pembaharuan instrumen berupa modifikasi kata-kata dan tambahan contoh hingga dapat meningkatkan ketepatan instrumen dan mengurangi galat.

Cognitive debriefing dilakukan dengan FGD. Mengingat bahwa ikhlas memiliki lebih dari satu makna yang dapat dipahami, maka pada awal sesi responden dimintai pendapatnya tentang makna ikhlas yang dipahami selama ini. Makna ikhlas tersebut dielaborasi lebih jauh hingga terlihat bentuk-bentuk indikatornya. Kemudian, untuk menggiring responden pada makna ikhlas dalam kontek penelitian ini, responden disajikan dua buah ilustrasi terkait ikhlas. Responden kemudian diminta untuk menyampaikan makna ikhlas berdasar ilustrasi tersebut. Sebagaimana dijelaskan sebelumnya, responden pada kelompok santri sepakat bahwa pergeseran makna tidak terlampau jauh. Definisi ikhlas sesuai konteks bersifat religius dan disandarkan dengan pengabdian pada Tuhan, tetapi dampak luarannya adalah kerelaan dan perbuatan-perbuatan yang tanpa pamrih sebagaimana definisi ikhlas secara umum.

Indikator-indikator ikhlas yang berhasil digali memiliki kesamaan prinsip penting sebagaimana yang dipaparkan oleh Chizanah (2009). Indikator ikhlas berdasar hasil FGD, yaitu tidak pamer merupakan salah bentuk bentuk dari aspek penting 
ikhlas, yaitu ketiadaan superiority feeling. Begitu pula keinginan untuk tampak menonjol atau politik pencitraan sebagai indikator tidak ikhlas merupakan salah satu contoh superiority feeling. Lillahita'ala, motif tunggal merujuk pada motif transendental dalam melakukan perbuatan. Munculnya respon 'lillahi ta'ala' dan segala sesuatu dari Tuhan secara implisit juga menunjukkan bahwa terdapat konsepsi mengenai Tuhan dan tugas pengabdian. Dengan demikian dapat dikatakan tidak ada gap antara ikhlas secara empiris dengan teoritis.

Uji reliabilitas yang dilakukan menunjukkan bahwa skor yang dimiliki skala ikhlas 0.809. Koefisien tersebut menunjukkan bahwa skala yang dihasilkan layak untuk digunakan sebagai instrumen pengukuran konstruk ikhlas.

Isu yang muncul dalam penyusunan skala ikhlas adalah patut-tidaknya melakukan pengukuran terhadap keikhlasan seseorang mengingat bahwa keikhlasan cenderung bersifat 'rahasia' atau laten, tidak terungkap. Perlu disadari bahwa semua konstruk dalam psikologi sifatnya adalah laten, tidak dapat diobservasi secara langsung. Inteligensi misalnya, tidak dapat dilihat atau diobservasi secara kasat mata dan dipastikan, tetapi yang dapat dilakukan adalah estimasi-estimasi melalui sejumlah aitem-aitem yang mengindikasikan kondisi inteligensi seseorang. Begitu pula ikhlas, sebagai sebuah konstruk psikologis yang memiliki sifat laten, maka pengukuran terhadapnya adalah sebuah bentuk estimasi untuk mendeskripsikan kondisi ikhlas pada diri seseorang. Selama sebuah konstruk dapat didefinisikan dan dijelaskan aspekaspeknya, maka konstruk tersebut memungkinkan diadakan observasi dan pengukuran terhadapnya (Kerlinger, 1992).

\section{SIMPULAN}

Luaran penelitian ini adalah skala ikhlas yang telah melalui uji validasi konten. Bermula dari 25 aitem yang disusun oleh peneliti berdasarkan aspek-aspek teoritis ikhlas, kemudian mengalami reduksi dan penambahan pada hasil professional judgement sehingga diperoleh 22 aitem yang valid, dilanjutkan dengan cognitive debriefing yang menghasilkan beberapa modifikasi dalam redaksi aitem, hingga akhirnya diujicobakan di lapangan dan memperoleh skor alpha-cronbach sebesar 0,809 . Koefisien reliabilitas tersebut menunjukkan bahwa skala yang disusun tergolong layak untuk menjadi instrumen pengukuran ikhlas.

\section{DAFTAR PUSTAKA}

Belzen, J. A. (2004) 'Spirituality, Culture, and Mental Health: Prospects and Risks for Contemporary Psychology of Religion'. Journal of Religion and Health, 43 (4), 291-316.

Boero, Boero, M.E., Caviglia, M.L., Monteverdi, R., Braida, V., \& Fabello, M. \& Zorzella, L.M. (2005) 'Spirituality of health workers: A descriptive study'. International Journal of Nursing Studies, 42, 915-921.

Bonab, B. G., Hamikirad, \& Habibi (2010) 'Relation between mental health and spirituality in Tehran University student'. Procedia Social and Behavioral Sciences, 5, 887-891.

Chally, P. S. \& Carlson, J. M. (2004) 'Spirituality, rehabilitation and aging: A literature review'. Arch Phys Med Rehabil Vol 85, Suppl 3, July 2004.

Chizanah, L. (2009) 'Konstruk Psikologi Ikhlas (Sebuah Kajian Hermeneutika atas Teks Ihya 'Ulumiddin Bab Ikhlas)'. Skripsi (tidak diterbitkan). Yogyakarta: Fakultas Psikologi UGM.

Corey, G. (2005).Theory and Practice of Counseling and Psychotherapy 7th Edition. Belmont: Brooks/Cole Thompson learning.

Cotton, S., Larkin, E., Hoopes, A., Cromer, B. A. \& Rosenthal, S. L. (2005) 'The impact of adolescent spirituality on depressive symptoms and health risk 
behaviors'. Journal of Adolescent Health, 36, 529-529.

Cotton, S., Zebracki, K., Rosenthal, S. L., Tsevat, J., \& Drotar, D. (2006) 'Religion/spirituality and adolescent health outcomes: a review'. Journal of Adolescent Health, 38, 472-480.

Hall, M. L. (2008) Self-Actualization Psychology: The Positive Psychology of Human Nature's Bright Side (Meta-Coaching Volume $I V)$. Clifton: Neuro-Semanthics Publications.

Henningsgaard, J. M. \& Arnau, R. C. (2008) 'Relationship between religiosity, spirituality, and personality: A multivariate analysis', Personality and Individual Differences, 45, 703-708.

Hood, R. W., Hill, P. C., \& Spilka, B. (2009). The Pychology of Religion: An Empirical Approach $4^{\text {th }} E d$. New York: The Guilford Press.

Kerlinger, F. U. (1992). Foundation of Behavioral Research $3^{\text {rd }}$ Ed. Terjemahan Landung R. Simatupang. Yogyakarta: Gadjah Mada University Press.

Khalil, A. (2007). Merengkuh Bahagia. Malang: UIN Malang Press.

King, J. R. (1988). 'Religion and Therapeutic Elements in Sufi Teaching Stories', Journal of Religion and Health, 27 (3), 221-235.
Muhammad, H. (2002). Dialog antara Tasawuf dan Psikologi : Telaah atas Pemikiran Psikologi Humanistik Abraham Maslow. Yogyakarta: Pustaka Pelajar.

Nizar, H. (2009). 'Integrasi Kajian Tasawuf dengan Psikologi'. Paper. Disajikan dalam Annual Conference Islamic Studies tanggal 3 November 2009 di Surakarta.

Ploughman M., Austin, M., Stefanelli, M., \& Godwin, M. (2010). 'Applying cognitive debriefing to pre-test patient-reported outcomes in older people with multiple sclerosis', Quality of Life Research, 19, 483487.

Qalami, A. F. (2003). Ringkasan Ihya' Ulumiddin. Surabaya: Gitamedia Press.

Subandi (2009). Psikologi Dzikir: Studi Fenomenologi Pengalaman Transformasi Religius. Yogyakarta: Pustaka Pelajar.

Sufi Muda. (2008) Ikhlas Berguru Kepada Wali Allah. Diakses tanggal 12 Juni $\begin{array}{llllll}2 & 0 & 1 & 1 & \mathrm{p} & \mathrm{a} d \mathrm{a}\end{array}$ http://sufimuda.wordpress.com.

Teschendorf, B. (2011) 'The role of cognitive debriefing and linguistic validation in instrument development and modification', CRF Health: Real Patient Data 24/7, 